\title{
Access to Credit and Investment Decisions of Small and Medium-Sized Enterprises in China
}

\author{
Paulo José Regis* \\ Xi'an Jiaotong-Liverpool University \\ China
}

August 2017

\begin{abstract}
:
Financial constraints are common in developing countries where financial systems are underdeveloped. In China, firms report that access to finance is the most important obstacle in the business environment. This is related to firms that fail to gain access to the credit market. We examine the likelihood of gaining access to credit by firms, and find that size and exporting appear to be the key characteristics. Credit constraints are significant for investment decisions. Together with size, access to credit is among the firm characteristics with the greatest impact on the likelihood to invest.
\end{abstract}

Keywords: access to finance, investment decisions, small and medium-sized enterprises, China

JEL code: G21, G32, O16, D52

*: BB440, Business Building, Xi'an Jiaotong-Liverpool University 111, Ren'ai Road, Dushu Lake Higher Education Town, SIP, Suzhou 215123, P.R. China email: paulo.regis@xjtlu.edu.cn, tel: +86(0)51288161705

Acknowledgements: This draft has benefited from useful comments when presented at the $3^{\text {rd }}$ International Seminar on Asia and Pacific Economies (XJTLU, Suzhou, China, 8-9 May 2015) 


\section{Introduction}

Financial constraints are an extended challenge in developing countries, and affect the generation of employment and sustained growth of firms. Financial services, and in particular, the availability of credit, are crucial for the efficient realisation of a firm's investment possibilities. Aware of the deficiencies of the financial sector of a country in transition towards a market oriented economy, the Chinese government has been proactive in reforming and modernising the banking and other financial sectors over the last 15 years.

This study is relevant to the literature on institutions and economic growth, and the importance of financial development as a facilitator of growth in particular. However, China is usually considered as a counter-example in cross-country studies. The Chinese financial system remains underdeveloped, while its economy is growing at a remarkable speed. The empirical literature has gone beyond country-level comparisons to look at firm-level data to complement the macroeconomic results with micro-level evidence. Over the last ten years, this literature has evolved to explore the role of external factors in the business environment, such as growth, productivity and employment, in the performance of firms. Heterogeneity across firms is of crucial interest, and can be very informative in estimating whether creditconstrained firms underinvest, which is the research question central to this paper.

We contribute to the previous studies of access to finance by Small and Medium-Sized Enterprises (SME). Access to finance is among the top concerns for businesses in China. Hallward-Driemeier et al. (2006) and Ayyagari et al. (2010) make use of the 2003 China Enterprise Survey. This is the first version of the World Bank survey in China, and was designed to examine access to finance in detail. Here, we make use of the most recent survey, from 2012, to study the firm characteristics more closely associated with access to finance. In comparison, the information on access to finance from the remaining 2005 survey is relatively poor, and has not previously been used. 
We define access to finance as having a loan, and find that firm size is among the most important factors to consider when assessing the likelihood of gaining access to credit in the financial sector. Small firms with less than 20 employees have a particularly low likelihood of accessing credit, while the gains from having a large firm are diminishing, especially for very large size firms (above 100 employees). We also contribute to the literature that relates access to finance with investment decisions. Access to credit itself is very important to allow firms to invest, while being an exporter increases the chances of accessing credit. Small firms also tend to be less likely to invest; however, the effect here is less strong than with access to credit.

One distinguishing characteristic of the dataset is that some of the most relevant variables are qualitative, truncated or censored. Surprisingly, most empirical studies ignore the importance of this limitation which may introduce a potentially large bias in their estimates. In our sample, the firm's investment and loans variables are censored around 50\% and 70\%, respectively. To handle limited and censored dependent variables, we make use of the Probit and Tobit models. The estimation of the credit and investment equations is simultaneous. When comparing the single equation and simultaneous estimations, the coefficient on access to credit is always significant but the latter more doubles the former.

Few studies have modelled the simultaneous relation between investment and access to credit. This paper proxies the financial constraints of the firm by its access to credit (i.e., financially constrained firms would not have access to credit), which is one of the firm characteristics taken into consideration for the decision to invest. Given the use of two limited dependent variables, the full structural model cannot be estimated since it is logically impossible (Maddala, 1983). Therefore, the structural investment equation is combined with the reduced form of the access to credit equation to obtain a recursive model.

The remainder of this paper is organised as follows. Section 2 revises the importance of access to finance in China, as well as the existing literature. Section 3 provides the theoretical background, while Section 4 introduces the econometric framework. The results are presented in Section 5, while Section 6 concludes the paper. 


\section{Access to finance of SMEs}

The World Bank Enterprise Survey is the most important effort to collect firm-level data on access to finance for SMEs in developing countries. It includes information on internal and external financing, among other firm characteristics. Previous studies have examined both subjective and objective indicators. Two subjective variables of access to finance from the 2012 China survey are summarised in Table 1. First, firms were presented with 15 external obstacles from the business environment and asked to select the most important. Second, firms were asked to rate how severe each of these obstacles are, on a scale ranging from 0 (no obstacle) to 4 (very severe obstacle). Access to finance was selected by $21 \%$ of firms, followed by an inadequately educated workforce, competitors' practices in the informal sector and tax rates, each at around 16\%. These were declared the most important constraints, with access to finance ranked top of them by an important margin.

Having a loan is an objective indicator of access to credit available in the survey. Access to credit is one the most important type of access to finance, and is at the core of the services offered by the financial market to firms. The other most important dimension of access to finance is deposits. Chinese firms seem not to be constrained by access to a bank account, with $95 \%$ of firms declaring having a cheque or savings account. Likewise, Fungáčová and Weill (2015) found that individuals have access to bank accounts, and that exclusion is mostly voluntary; however, this is not the case for access to credit in the formal financial sector. Compared to other BRICS nations, formal credit is less developed in China.

Table 2 suggests that the fact that financial access is reported as the main obstacle may be related to access to credit in particular. Around $31 \%$ of the firms surveyed had access to credit. Comparing the sample of firms for which access to finance is the top obstacle to the other firms, the former group makes over 10\% more applications for loans than the latter group (34.1\% vs $22.3 \%$ ), suggesting they are more active at seeking access to finance than the average company. In addition, the firms that did not apply for a loan did not give "no need for a loan' as their main reason. Only $21.8 \%$ of the firms that reported access to finance as the 
most important obstacle and that had not sought access to credit stated that they did not need a loan, compared to $65.1 \%$ of the other firms. Instead, $41.5 \%$ reported that the firm did not make an application because either the cost (interest rates) or the collateral requirements were too high. This is a threefold increase relative to the $13.1 \%$ of firms for which access to finance was not the main obstacle. Likewise, the share of firms that declared the size or maturity of the loan was insufficient $(12.3 \%)$ was more than double the one of the second sample, where access to finance was not an obstacle (5.2\%). Together, these three factors explain more than half of the cases where the firm did not apply for a loan when access to finance was the main obstacle.

The literature has focused on two complementary directions: the analysis of financial constraints and the impact of those constraints on the performance of a firm. Previous studies have identified size as one of the firm characteristics important for access to finance. Beck et al. (2005) regressed an ordinal firm-level indicator of financial access (ranging from 1, where financing is no obstacle to 4 , where financing is a major obstacle) on certain firm and country characteristics, and found that small firms have significantly higher financial obstacles than large firms. Aterido et al. (2007) also found that small firms have significantly less access to finance, even when controlling for other firm characteristics, such as age, export status and ownership. Likewise, small firms tend to finance much less of their investment from the formal financial sector. Bigsten et al. (2003) reported that almost two-thirds of firms with five or less employees in Africa are credit-constrained, compared to only $10 \%$ of firms with 100 or more employees. Their estimates suggest that the likelihood of a successful loan application is positively related to firm size.

The identification of financial constraints has led to studies such as those of Beck et al. (2005), Hallward-Driemeier et al. (2006) and Ayyagari et al (2010) that measure the importance of these constraints on firm performance in terms of sales growth, employment growth and productivity. In particular, some empirical studies focus on the effect of liquidity constraints on investment. They have relied extensively on cash flow as a proxy for capital 
markets imperfections. ${ }^{1}$ For Chinese firms, this literature includes Poncet et al., 2010, Guariglia et al., 2011, Firth et al., 2012 and Tsai et al., 2014. However, Kaplan and Zingales, (1997 and 2000) provide good reasons that advocate that liquidity may not be a good indicator for that kind of financial constraints. This is a measure of the ability to generate internal resources which are promptly available, while there are other measures available more directly related to external financial resources made available to the firm. This study makes use of the stock of loans of the firm as the key measure of access to finance. Other studies of Chinese firms that have preferred a similar proxy of external financing are Ayyagari et al. (2010) and Chong et al. (2013). Few studies have modelled the simultaneous relation between firm investment and financial constraint.

Some studies have used a third proxy of access to finance the proportion of investment financed by new loans. However, the use of new loans for investment as the measure of financial constraints causes some challenges. Given that firms can only receive loans for investment if they already have decided to invest, a common concern is the endogeneity of bank financing decisions. The Bivariate Probit model with sample selection (i.e., the Heckman model) is the appropriate framework to deal with this endogeneity. Bigsten et al. (2003) and Ayyagari et al. (2010) have both followed this framework for the African countries and China, respectively. Our proxy of access to finance is the stock of loans (no matter if they are used for investment or other purposes), which does not suffer from the same selection issue, since it is observed for both firms that invest and the ones that do not.

\section{Theoretical framework}

There are two approaches that dominate the literature: the q-theory model (e.g., Fazzari et al., 1988, and Gilchrist and Himmelberg, 1999) and the euler equation model of investment (e.g., Bond and Meghir, 1994, Gilchrist and Himmelberg, 1999). These theoretical models depart

\footnotetext{
${ }^{1}$ This is motivated by the assumption that the two sources of financing for SMEs are retained earnings and loans, and the fact that data on the cash flow of the firm is more easily available. Generally, studies with cash flows as the financial constraint variable are related more directly to the q-theory of investment.
} 
from the firm's expected future profitability. The introduction of capital market imperfections raises the presence of financial constraints in investment decisions, contrary to the Modigliani-Miller theorem obtained from the traditional neoclassical model. The optimal path of investment $\left(I_{t}\right)$ can be obtained from the first order conditions.

The general form of the investment function would be $I / K_{t}=I\left(I / K_{t-1}, L_{t}, Y_{t}\right)$ where $L_{t}$ is loans, our proxy for access to credit, while vector $Y_{t}$ groups all other factors that may affect investment (age, size, etc). This would be the investment equation to be estimated, with $L_{t}$ being the financial constraint variable. Typically, additional assumptions are made to obtain a linear function with an additive error term. A Negative coefficient of $L$ may reflect the negative effect of financial constraints.

This type of dynamic investment equation provides the general framework followed by most previous empirical studies, such as Bond et al. (2003), Love (2003), Poncet, et al. (2010), Bertoni et al. (2013) and Engel and Stiebale (2014), among others. These firm-level studies have been mostly concerned with this single equation estimation with emphasis in its time series elements, employing Arellano and Bond (1991) and Blundell and Bond (1998) Generalized Method of Moment (GMM) estimators. However, these studies still ignore probably the most important characteristic of the data: investment and loans most likely are heavily left-censored at zero. Censoring would imply the instruments would also be censored since they are lagged values.

Further, lagged variables are not generally available in our dataset, including investment in particular. Therefore, this may not be the best approach to our needs. Instead we can focus on the steady state solution of investment $\left(I^{*}\right)$ and capital $\left(K^{*}\right)$. Since the steady state involves a constant investment to capital ratio $\left(\vec{l}^{*}\right)$, the level of investment is proportional to the steady state of capital and the dynamics disappear Assuming the firms are mostly near their steady state, investment is $I^{*}=\vec{\imath}^{*} K^{*}$. Tthe investment function becomes

$$
I=I(L, Z)
$$


where $Z^{\prime}$ comprises the steady state determinants other than $L .{ }^{2}$ Under market imperfections, the availability of credit affects the steady state of capital, therefore, affecting steady state investment.

The time subscript is omitted since dynamic effects are excluded. This approach neglects the adjustment process to the new equilibrium; however, this is the approach that fits our data. This is a common limitation of the World Bank Enterprise Survey. In few countries firms have been observed more than one period, China not being one of them.

So far, we have modelled investment decisions. Next, we look at access to credit, where the market for loans is summarized by a reduced from equation. The demand for loans of the firm $L^{d}\left(i r, I, X^{d}\right)$ is a function of the interest rate (ir ), investment and other firm characteristics grouped in vector $X^{d}$. This demand for loans include other uses that investment (e.g., working capital), which motivates the inclusion of other firm characteristics in $X^{d}$. In addition to $i r$, the supply of loans $L^{s}\left(\right.$ ir, coll,profit, growth, size, age,$\left.X^{s}\right)$ would depend on the firm's collateral availability (coll), credit worthiness and some additional firm characteristics. With collaterals and credit worthiness, banks aim at limiting the moral hazard problem. Credit worthiness is proxied by the firm's profit and growth, two variables that are related to the good performance and profitability of the firm.

Two extra variables considered as indicators of credit worthiness are the firm's age and size. Vector $X^{s}$ may include other firm characteristics. Export status could be firm characteristic observable by banks included in $X^{s}$. Having access to a larger potential market may be an indicator of the capacity to pay back its debt. There may be other firm characteristics related to credit worthiness that are desirable to know; however, banks may not have access to some of them since they are internal information to the extent that the firm may hide some activities.

Assuming the market for loans clears, the reduced form loan equation takes the form

\footnotetext{
${ }^{2}$ The main determinants of $\vec{l}^{*}$ are the depreciation rate and intertemporal discount rate. Depending on the assumptions of the model, additional factors may affect $\bar{l}^{*}$; for example, the technology parameter in a CobbDouglas production function or the adjustment-cost function. Most of these factors would also be part of the determinants of $K^{*}$.
} 


$$
L=L(I, \text { coll, profit, growth, size, age } X)
$$

where $X$ is a vector that combines $X^{d}$ and $X^{s}$. A similar reduced from equation for the loans market has been used by Johnson et al (1999) and Bigsten et al. (2003). The analysis of investment and access to credit presents some challenges, according to equations (1) and (2). This system of equations suggests both investment and loans may be endogenous.

\section{Econometric framework}

Assuming equations (1) and (2) can be linearised and adding an error term to each, the structural equations can be expressed as

$$
\begin{aligned}
& I_{i}=\beta_{0}^{I}+\beta_{1}^{I} L_{i}+Z_{i}^{\prime} \theta^{I}+\varepsilon_{i}^{I} \\
& L_{i}=\beta_{0}^{L}+\beta_{1}^{L} I_{i}+X_{i}^{\prime} \theta^{L}+\varepsilon_{i}^{L}
\end{aligned}
$$

Our framework avoids lags of $I_{i}$ and $L_{i}$. Linearised investment functions are common in the relevant literature and a linear loans function can be obtained from the log-linear supply and demand of the loans market. Alternatively, the reduced form equations are

$$
\begin{aligned}
& I_{i}=\alpha_{0}^{I}+W_{i} \gamma^{I}+u_{i}^{I} \\
& L_{i}=\alpha_{0}^{L}+W_{i} \gamma^{L}+u_{i}^{L}
\end{aligned}
$$

where $W_{i}$ is a vector that combines variables from both $Z_{i}$ and $X_{i}$.

Since the two dependent variables are not observed when a firm decides not to invest or apply for loans, these two corner restrictions may introduce a bias. The linear regression model becomes inappropriate for both the structural and reduced forms. Instead, the Probit and Tobit models are proposed to deal with the limitations of the dependent variables. 


\subsection{The Probit equation}

Let credit $_{i}$ be a dummy variable ( 1 if the firm has credit, 0 otherwise) while invest $_{i}$ may also be defined as a binary choice between investing (invest $=1$ ) or not (invest $=0$ ). Variables $I_{i}$ and $L_{i}$ may not be observed when $I_{i}<0$ and $L_{i}<0$ but invest $t_{i}$ and credit $_{i}$ are correctly observed. Investment decisions and access to credit can be modelled using a latent variable approach based on either the structural or reduced form equations. For example, a firm's propensity to invest, given equation (3) and the firm's characteristics in $Z_{i}$, may be defined as:

$$
P\left(\text { invest }_{i}=1 \mid L_{i}, Z_{i}\right)=F\left(\beta_{0}^{I}+\beta_{1}^{I} L_{i}+Z_{i}^{\prime} \theta^{I}\right)
$$

where $F($.$) is the cumulative distribution function and, assuming this is the standard normal$ distribution function, will lead to the estimation of the Probit model.

Most investment studies that use the Probit model estimate the single structural equation (7). Making use of equation (4), a Probit specification for credit $_{i}$ can be obtained that, together with the previous Probit equation for investment, would become the binomial Probit, or Biprobit, version of the same simultaneous equation structural model (3) and (4). However, the endogeneity of credit and invest is still a relevant issue for the estimation of either a single equation or a two-equation system.

Further, there is a well-known limitation of logical consistency (see Maddala, 1983, Chapter 5), which is necessary for the bivariate distribution of invest ${ }_{i}$ and credit $_{i}$ to be well specified. Lewbel (2007) shows the consistency condition of the structural model is equivalent to requiring a valid reduced form system. The condition for logical consistency in the Probit structural equations is $\beta_{1}^{L} \beta_{1}^{I}=0$. That is, either loans need to be excluded from the investment equation $\left(\beta_{1}^{L}=0\right)$ or investments must be excluded from the credit equation $\left(\beta_{1}^{I}=0\right)$. Imposing one of these two conditions will transform the system into a recursive (triangular) model; therefore, this would also imply the two equations' conditions for identification are met and instrumental variables are not required. 
One possible strategy is to make use of the credit equation in its reduced form together with equation (7) for investment. The Probit credit equation takes the form

$$
P\left(\text { credit }_{i}=1 \mid W_{i}\right)=F\left(\alpha_{0}^{L}+W_{i} \gamma^{L}\right)
$$

Then, the parameter of investment in the credit equation can be set to zero, meeting the consistency condition. The estimation of the recursive system of equations (7) and (8) is reasonable if access to credit can be considered as an exogenous regressor of investment in equation (7), a hypothesis that will also be formally tested. Therefore, estimation of the Biprobit model of Heckman (1978) becomes adequate.

Few studies have followed a system of equations approach. From previous studies, only Bigsten et al. (2003) make use of the Biprobit model, but they estimate two credit equations, while investment is not included. The credit market is modelled as having a sequential twostage mechanism: a credit application equation (demand side) and a credit assignation equation (supply side). Other empirical models have proposed the use of a recursive system to reach the consistency condition. The Heckman model with sample selection (Heckman, 1979) combines a continuous dependent variable (the main variable of interest) and a limited dependent variable (the treatment equation, which does not include the main variable of interest and can be interpreted to be in reduced form). The latter is the approach favoured by Ayyagari et al. (2010) to relate investment spending and access to credit, combining equations (3) and (8). Rivers and Vuong (1988) rely on a system of two equations with a structural Probit for the limited dependent variable, which is the main variable of interest, and a reduced form equation for the second variable of interest, which is continuous. This type of estimator can be used for a system with equations (7) and (6) for investment and loans, respectively, although this has not been implemented in any study so far.

\subsection{The Tobit equation}


Equation (3) can be estimated by the standard Tobit model for $I_{i}$. Since logical consistency is still an issue, loans is still represented by its reduced form, equation (6). This is a recursive system with two censored variables that can be estimated by the bivariate Tobit model. This nonlinear model can also be referred as the censored regression model. Although it makes better use of the information of the non-censored data, the coverage of the sample is reduced since some firms are reluctant to provide figures rather than responding to yes/no questions. Further, the lost information is uncensored observations. This is particularly worrisome for loans: around $34 \%$ of the firms that stated that they had a loan or line of credit either refused to provide the amount or stated that the amount was not known. Likewise, around $18 \%$ of the firms that stated they had made an investment in the year 2011 did not provide the amount.

\section{Results}

The data is from the 2012 World Bank Enterprise Survey for China, which includes 2,700 firms from 25 urban cities across 12 provinces. The sample is intended to be representative of the country's private sector. The main objective of the survey is to ascertain the characteristics of the business environment, including access to finance. It covers many characteristics of firms related to infrastructure, bribery, crime, financing and credit, competition and informality, land and permits, business-government relations, among others. Table 3 presents summary statistics of the variables. City and industry dummies are included in all specifications to control for factors other than firm characteristics.

Given the censored nature of the data, we apply a limited dependent variable framework. The credit and investment equations are jointly estimated in section 5.3. Since the Biprobit and Bitobit models require the system of equations to be recursive to avoid logical inconsistency, the reduced form of the credit equation and the structural equation of investment are selected. These results can be compared with the single-equation estimation of each of the two equations. The reduced equation of access to credit is estimated in section 5.1 while the structural equation of investment is estimated in section 5.2. 


\subsection{Access to credit}

Table 4 is based on equation (8) for alternative specifications of firm characteristics. Since the credit equation is in its reduced form, determinants of both $I_{i}$ and $L_{i}$ are included. They are firm characteristics mostly motivated by results in previous studies: size, export condition, ownership, manager characteristics, age, collateral accessibility (land proprietorship) and credit worthiness (sales growth and profits). Some of them were already presented in the theoretical framework in section 3. City fixed effects intend to control for economic and financial system level of development, regional policy and workforce composition. The potential influence of industry fixed effects, such as the degree of market power, industrial policy and capita intensity, are also taken into account using dummy variables. As shown at the bottom of the table, the number of firms for which credit $=1$ is around $31-32 \%$ of the sample.

Firm size is measured by the number of full-time (either permanent or fixed-term contract) employees (in logs). A quadratic function of employment seems to provide a good fit, since the coefficient of the squared term is statistically significant. The positive and negative signs of the coefficients of the linear and quadratic terms suggest firm size is associated with a higher probability of gaining access to credit, although gains of a larger size seems to be less important as the firm grows. Two dummy variables, SME1 and SME2, are also included in regression (2) to consider small (20 or less employees) and medium (between 21 and 99 employees) sized firms, respectively. Of these two, only SME1 is statistically significant. The coefficient is large and negative, so firms with 20 or less employees are considerably less likely to obtain credit. Interestingly, firm size has been used as a proxy for firms being financially unconstrained in Faulkender and Petersen (2006) and Hadlock and Pierce (2010). The observation that large firms are less likely to face financial constraints may be useful in this context. 
Three explanatory variables are censored at zero: exports, foreign ownership and state ownership. ${ }^{3}$ The large mass of zeros is a concern since censored observations usually introduce nonlinearities. For each, a dummy variable for whether the observations are censored are included. Regression (3) include these six regressors, where only exports and the dummy variable for exporters are significant, while state ownership is significant when its dummy is not included. Being an exporter has a large and positive effect on having a better chance of obtaining credit. From regression (3) to (7), given exporting status that enhances credit access, firms with larger export shares have a diminishing effect on the probability of gaining credit. On the other hand, firms with large government ownership have fewer chances to access loans. Since the financial sector is dominated by state-owned banks, the negative sign of state ownership is contrary to our expectations. Poncet et al. (2010) and Guariglia et al. (2012) conclude state-owned Chinese firms are not credit constrained. A possible interpretation of the negative coefficient is that state-owned firms have less need of credit to carry out their activities than private firms, even if it is relatively easy to get a loan for them. Given the increasing role of the private sector in China to generate employment, the private sector may have a higher demand for external financing.

Figure 1 summarises most of these findings. The top chart is the histogram of employment, distinguishing small (20 or less employees), medium (between 20 and 100) and large firms (100 or more). The bottom chart is the predicted probability of the average firm of having access to credit given the size of the firm. Other firm characteristics, except firm size and exporting, are fixed at the sample mean. Exporters (dashed line) have a large advantage in gaining access to credit over firms that produce for the domestic market only (solid line) at all firm sizes. Very few firms are so large that they can be found beyond the turning point of the curve: less than $0.3 \%$ have a size (in logs) of over 8.99 (i.e. 8,000 employees or more). Therefore, firm size has a positive effect on the likelihood of gaining access to credit. There are positive but diminishing gains with an increase in firm size, as well as the large and

\footnotetext{
${ }^{3}$ They are also right-censored (at 100); however, this happens far less often: fully foreign-owned firms and fully exportoriented firms are only $2 \%$ and $3 \%$ of the sample respectively, while no firm is completely owned by the government. Rightcensored observations have been dropped.
} 
negative effect of being a small firm. From these two, the negative effect of being a small firm has the largest impact on the credit possibilities of the firm. Around $22 \%$ of our sample was affected by this small size effect.

Other control variables that were considered but are not statistically significant include a business group dummy and a listed firm dummy. Regression (4) suggests sex discrimination is not an important issue to access to credit. Age is another variable that seems not to influence access to credit (regression 5). Other alternative specifications of age were considered, but none were statistically significant. ${ }^{4}$

The last two columns consider the availability of land as collateral and the performance of the firm. These factors may be important for the financial institution to make a decision on whether to grant a loan to the firm. Since firms in the services sector do not provide information on machinery and equipment, land is the most important asset to be used as collateral for which information is available for the full sample. The highly significant and positive coefficient on land in regression (6) is consistent with this interpretation. Although the land dummy becomes nonsignificant in regression (7), it will be again significant (at 10\%) in Table 6, as expected. Therefore, we consider the land dummy is mostly consistent with our expectations although it shows some mixed results. In regression (7), growth (i.e., growth rate of sales) and profitability (i.e., mark-up over cost of sales) are included as two proxies of credit worthiness. They are statistically significant and with the expected sign.

Interestingly, size may be a proxy for collateral capability. Large firms have more assets (e.g., machinery, property) which can be used as collateral when applying for credit. This would explain the positive effect of size on access to credit described before. On the other hand, size may be related to credit worthiness since it can be an indicator of internal financial resources capability. The banking sector may be willing to provide loans to large firms because they can generate more internal resources to make future payments. Similarly, firm size could be an indicator of its reputation (Hooks, 2003 and Diamond, 1991) since large firms are more likely to be well known in the economy. Size as indicator of both internal resources and

\footnotetext{
${ }^{4}$ These include the quadratic function, age in logarithms, the quadratic function in logarithms and dummy variables for age (i.e., fixed effects). Due to space limitations, the results are not presented here.
} 
reputation suggests large firms are more attractive to banks. For any given loan size, large firms are in a better position to generate resources to pay back. That is, firm size becomes a proxy of credit worthiness, in addition to profitability and firm growth, in the supply of credit (see section 3). Export status may be another observable firm characteristic banks take into account when examining the credit worthiness. Companies that export have an advantage since their potential market is larger than other firms, having a better prospect to pay back its debt. Muûls (2015) finds support to the relationship of the decision of exporting/importing with credit constraints and credit rankings.

\subsection{Investment decisions}

Among the positive effects access to credit may have on SMEs, promoting investment is of special interest to policymakers. Given that only around one-third of the firms had obtained credit, while $21 \%$ consider access to finance as their major obstacle to growth, access to credit may have a strong effect on investment. Table 5 is the Probit estimation of equation (7). Around $51-52 \%$ of the sample showed some positive investment decision, compared to the $31-32 \%$ that had a loan. This is explained by the fact that the most important source of investment is internal funding.

The endogeneity test of access to credit is reported at the bottom of Table 5. It makes use of three instrumental variables: SME1 (dummy for small firms), the land ownership dummy and profitability. In section 3, both collaterals and profitability are part of the supply of loans since these are two variables banks revise in loan applications. Land ownership is the most important collateral of the firm, especially in the service sector. Most loans in China are backed by land and buildings as collateral. Since collaterals do not affect investment other than by facilitating access to credit, it is a good candidate for an instrumental variable. Collateral has been used as an instrument for loans in the investment equation in Johnson et al. (1999) and Ayyagari et al. (2010).

Part of the literature have used profitability as an alternative proxy for credit constraints. If access to finance were not a concern, the Modigliani-Miller theorem would apply and the 
choice of financing source (loans, retained earnings and new equity) would be irrelevant for investment; therefore, profitability would not have any influence in investment. Profitability as an indicator of credit worthiness has been selected as another instrument for access to credit. In Table 4, the dummy for small firms may reflect the discrimination small firms suffer in the financial sector when making a loan application. This information on the effect of size on credit constraint can be useful as an instrument since a similar effect of the dummy for small firms on investment is not observed in the investment equation.

In all regressions, the endogeneity test suggests access to credit can be treated as an exogenous regressor since the null of exogeneity can be rejected. Thus, the Probit model is a consistent and efficient estimator of equation (7). The variable credit is strongly significant and positive, suggesting access to the financial sector is an important factor when a firm is making the decision whether to invest or not. Greater access to finance would be associated with more firms investing, and therefore it seems that constraints in the Chinese financial market may be affecting efficient allocation choices. From Table 4, small firms, which tend to suffer from large financial constraints, may be particularly affected by access to credit. When examining firm size directly, we again find a positive but decreasing effect; however, neither the small nor medium firm size dummies (even if considered each individually) had a significant effect.

Figure 2 shows the positive effects of both firm size and access to credit on the likelihood of investing. The turning point is 7.82 (i.e., 2,500 employees), with only $1.2 \%$ of the firms being bigger than this threshold. The effect of firm size is quite large: even if the firm does not have access to credit, a large typical firm may have a likelihood of investing of 52-65\%, compared to only $19-35 \%$ for a typical small firm. Also, the two curves are steep for small and medium size firms. The distance between the dashed and solid lines shows the gain in the probability of investing with having access to credit for different firm sizes. Firms with credit are about $15 \%$ more likely to invest than when credit $=0$. Typically, firms of all sizes with access to credit have a likelihood of investing of more than $32 \%$ (dashed line). 
State ownership and the dummy for exporters are both statistically significant. State ownership seems to have a negative effect on investment, which is not surprising if publiclyowned companies are less influenced by business opportunities. The observed result of a positive effect of exporting on investment decisions is as expected. On the other hand, the negative sign of the female ownership dummy variable was not expected, given that it was not significant in Table 4. The dummy for female managers is still not significant. Age is significant in regression (12) but only at $10 \%$. However, age is excluded from future specifications because it becomes nonsignificant. In regression (13), growth is also significant, while profit is not.

\subsection{Loans and investment}

The system estimation of the two equations is performed in Table 6 . The endogeneity test at the bottom of the table shows the proxy for access to credit (i.e., either credit or loans) can be treated as exogenous, which is in favour of the recursive system interpretation of the structural model. The first two columns of Table 6 reproduce the Probit estimation of equations (7) and (8) separately with the most significant variables of Tables 4 and 5, respectively. The results do not change quantitatively.

In the next two columns, equations (7) and (8) are jointly estimated by the Bivariate Probit model. This is the recursive system of the investment equation and the reduced form equation for the credit market, in which the correlation of the disturbances of the two equations is estimated to be -0.37 . The sign and size of the coefficients have not changed greatly, except for credit in the investment equation (regression 17), which more than doubled (and is still significant at $1 \%$ ). The estimation of the Biprobit model suggests that access to credit is now the most important factor in the decision to invest. Also, land ownership (proxy for collaterals) become statistically significant at $10 \%$ level.

Next, the two limited dependent variables were replaced by loans $(L)$ and investment $(I)$, both in logarithms, the censored variables from equations (3) and (6), respectively. Notice that loans is included in the investment equation, forming the triangular system. In regressions 
(18) and (19), the loans and investment equations are estimated separately. The same estimation is made in the context of the Bivariate Tobit model in regressions (20) and (21), with a significant correlation coefficient of the error terms of -0.36 , which is very similar to the Biprobit model. The significant coefficient of loans also shows the positive effect of an increase of access to credit. As with the Biprobit estimates, this coefficient more than doubles when the investment and loans equations are estimated jointly.

However, when examining the other variables some become non-significant, especially in the Bitobit model and the loans equation. For example, for firm size, the quadratic term is no longer significant in regression (18), while the linear term is also non-significant in regression (20). However, the negative sign of the coefficient of the SME dummy for firms with 20 or less employees is still large and statistically significant. Some other variables also become non-significant, but this may also be the result of the loss of observations since the sample is reduced by around $15 \%$. Most lost observations correspond to firms that invest and have loans: more than $21-22 \%$ of the observations where firms invest are not observed in the Tobit regressions, while this number increases to more than $30-35 \%$ of the observations where firms have access to credit.

\section{Conclusions}

The importance of access to finance for SMEs has been highlighted many times in the international literature. The development of an appropriate financial system has become an important goal in many developing countries. Although the economy has been booming for many years, China in particular has an underdeveloped financial system. The development of the financial sector as potential engine of economic growth of the private sector is at the top of the priority list of public policy.

This study makes use of one of the most recent surveys of Chinese firms, with 2,700 observations. The financial sector is failing to support firms as much as is needed. Although half of the surveyed firms participate in investment, this is an economy where only $30 \%$ or less of firms report having access to credit. Instead, the most important sources of finance are 
internal to the firm. However, our results suggest that access to credit is an important factor in the decision to invest, and perhaps the most important firm characteristic related to investment decisions. Likewise, the size of the firm was shown to be among the most important firm characteristics for gaining access to credit. In particular, small firms with 20 or less employees have a considerably lower chance to gain access to credit. Other firm characteristics that positively influence access to credit are being an exporter and manager experience. 


\section{References}

Arellano, M and S R Bond (1991) "Some Tests of Specification for Panel Data: Monte Carlo Evidence and an Application to Employment Equations." Review of Economic Studies 58:277-297.

Aterido, R, M Hallward-Driemeier and C Pagés (2007) "Investment Climate and Employment Growth: The Impact of Access to Finance, Corruption and Regulations across Firms." IDB Publications (Working Papers) 43618, Inter-American Development Bank.

Ayyagari, M, A Demirgüç-Kunt and V Maksimovic (2010) "Formal versus Informal Finance: Evidence from China." Review of Financial Studies 23:3048-3097.

Beck, T, A Demirgüç-Kunt and V Maksimovic (2005) "Financial and Legal Constraints to Growth: Does Firm Size Matter?” The Journal of Finance 60:137-177.

Bertoni, F, M Ferrer and J Marti (2013) "The Different Roles Played by Venture Capital and Private Equity Investors on the Investment Activity of their Portfolio." Small Business Economics 40:607633.

Bigsten, A, P Collier, S Dercon, M Fafchamps, B Gauthier, J W Gunning, A Oduro, R Oostendorp, C Pattillo, M Söderbom, F Teal and A Zeufack (2003) "Credit Constraints in Manufacturing Enterprises in Africa." Journal of African Economies 12:104-125.

Blundell, RW and S R Bond (1998) "Initial Conditions and Moment Restrictions in Dynamic Panel Data Models." Journal of Econometrics 87:115-143.

Bond, S and C Meghir (1994) "Dynamic Investment Models and the Firm's Financial Policy." Review of Economic Studies 61:197-222.

Bond, S R, J A Elston, J Mairesse and B Mulkay (2003) "Financial Factors and Investment in Belgium, France, Germany, and the United Kingdom: A Comparison Using Company Panel Data." Review of Economics and Statistics 85:153-165.

Engel, D and J Stiebale (2014) "Private Equity, Investment and Financial Constraints: Firm-Level Evidence for France and the United Kingdom.” Small Business Economics 43:197-212.

Fazzari, S M, R G Hubbard and B C Petersen (1988) "Financing Constraints and Corporate Investment.” Brookings Papers on Economic Activity 1988:141-195.

Fungáčová, Z and L Weill (2015) "Understanding Financial Inclusion in China." China Economic Review 34:196-206. 
Gilchrist, S and C Himmelberg (1999) "Investment, Fundamentals and Finance." In B S Bernanke and J Rotemberg (eds), NBER Macroeconomics Annual 1998, pp. 223-274. Cambridge, Mass.: MIT Press.

Gilchrist, S, J W Sim, E Zakrajšek (2014) "Uncertainty, Financial Frictions, and Investment Dynamics.” NBER Working Paper No. 20038.

Hallward-Driemeier, M, S Wallsten and L C Xu (2006) "Ownership, Business Climate and Firm Performance: Evidence from Chinese Firms.” Economics of Transition 14:629-647.

Heckman, J J (1978) "Dummy Endogenous Variables in a Simultaneous Equation System." Econometrica 46:931-959.

Heckman, J J (1979) “Sample Selection Bias as a Specification Error.” Econometrica 47:153-161.

Johnson, S H, J McMillan and C M Woodruff (1999) "Property Rights, Finance, and Entrepreneurship.” CESifo Working Paper Series 212, CESifo Group, Munich.

Lewbel A (2007) "Coherency and Completeness of Structural Models Containing a Dummy Endogenous Variable.” International Economic Review 48:1379-1392.

Love, I (2003) "Financial Development and Financial Constraints: International Evidence from the Structural Investment Model.” Review of Financial Studies 16:765-791.

Maddala, G S (1983) "Limited-Dependent and Qualitative Variables in Economics." Cambridge University Press: New York.

Poncet, S, W Steingress and H Vandenbussche (2010) "Financial Constraint in China: Firm-level Evidence." China Economic Review 21:411-422.

Rivers, D and Q H Vuong (1988) "Limited Information Estimators and Exogeneity tests for simultaneous Probit Models." Journal of Econometrics 39:347-336.

Faulkender, M., and M. A. Petersen (2006) "Does the Source of Capital Affect Capital Structure?" Review of Financial Studies 19:45-79.

Hadlock, C. J. and J. R. Pierce (2010" "New Evidence on Measuring Financial Constraints: Moving Beyond the KZ Index”. Review of Financial Studies 23:1909-1940.

Muûls, M. (2015) "Exporters, importers and credit constraints". Journal of International Economics 95:333-343.

Diamond, D. (1991) "Monitoring and reputation: the choice between bank loans and directly placed debt”. Journal of Political Economy 99:689-721. 
Hooks, L. (2003) "The impact of firm size on bank debt use". Review of Financial Economics 12:173-189.

Guariglia, A., X. Liu, and L. Song (2011) "Internal finance and growth: Microeconometric evidence on Chinese firms". Journal of Development Economics 96:79-94

Firth, M., P. Malatesta, Q. Xin and L. Xu (2012) "Corporate investment, government control, and financing channels: Evidence from China's Listed Companies". Journal of Corporate Finance 18:433-450

Tsai, Y.J., Y.P. Chen, C.L. Lin and J.H. Hung (2014) "The effect of banking system reform on investment-cash flow sensitivity: Evidence from China". Journal of Banking \& Finance 46:166-176

Kaplan, S.N. and L. Zingales (1997) "Do Investment-Cash Flow Sensitivities Provide Useful Measures of Financing Constraints?” The Quarterly Journal of Economics 112:169-215.

Kaplan, S.N., and L. Zingales (2000) "Investment-Cash Flow Sensitivities are not Valid Measures of Financing Constraints". The Quarterly Journal of Economics 115:707-712.

Chong, T.T., L.Lu and S. Ongena (2013) "Does banking competition alleviate or worsen credit constraints faced by small- and medium-sized enterprises? Evidence from China". Journal of Banking \& Finance 37:3412-3424 
Table 1. Obstacles in the business environment

\begin{tabular}{lrrrrrrr}
\hline & \multicolumn{3}{c}{ Biggest } & \multicolumn{7}{c}{ Degstacle (intensity) of obstacle (\%) } \\
& Obs & \multicolumn{1}{c}{$(\%)$} & 0: None & 1: Mi & 2: Mo & 3: Ma & 4: Very \\
serate & jor & severe \\
\hline Do not know / Does not apply & 101 & 3.74 & & & & & \\
Access to finance & 566 & 20.96 & 43.30 & 37.01 & 15.31 & 3.71 & 0.67 \\
Access to land & 128 & 4.74 & 53.84 & 34.05 & 9.21 & 1.86 & 1.04 \\
Business licensing and permits & 20 & 0.74 & 72.39 & 22.55 & 3.87 & 0.86 & 0.33 \\
Corruption & 31 & 1.15 & 75.12 & 20.27 & 3.62 & 0.72 & 0.26 \\
Courts & 6 & 0.22 & 76.49 & 20.33 & 2.83 & 0.23 & 0.11 \\
Crime, theft and disorder & 16 & 0.59 & 76.28 & 20.56 & 2.49 & 0.26 & 0.41 \\
Customs and trade regulations & 42 & 1.56 & 77.96 & 18.45 & 3.05 & 0.42 & 0.12 \\
Electricity & 129 & 4.78 & 62.92 & 27.85 & 7.49 & 1.00 & 0.74 \\
Inadequately educated workforce & 434 & 16.07 & 44.53 & 37.12 & 15.50 & 2.45 & 0.41 \\
Labour regulations & 49 & 1.81 & 59.64 & 30.91 & 8.19 & 1.07 & 0.19 \\
Political instability & 20 & 0.74 & 78.24 & 17.19 & 3.51 & 0.76 & 0.30 \\
Practices of competitors (informal sector) & 427 & 15.81 & 40.40 & 37.33 & 17.75 & 3.67 & 0.86 \\
Tax administration & 108 & 4.00 & 46.21 & 27.71 & 18.16 & 6.65 & 1.26 \\
Tax rates & 420 & 15.56 & 52.01 & 28.13 & 16.48 & 2.79 & 0.60 \\
Transport & 203 & 7.52 & 60.81 & 29.14 & 7.78 & 1.53 & 0.74 \\
Total & & & & & & & \\
\hline
\end{tabular}

Notes: The 'biggest obstacle' refers to the global question 'What is the biggest obstacle from the business environment?', and presents two columns: the number of firms and the percentage that have chosen each obstacle. The 'degree of the obstacle' is the percentage of firms that responded to each obstacle, the degree of difficulty ranges from 0 (no obstacle) to 5 (very severe obstacle).

Table 2. Access to credit

\begin{tabular}{lrrrr}
\hline & $\begin{array}{c}\text { Access to finance } \\
\text { is main obstacle } \\
\text { sample }\end{array}$ & $\begin{array}{c}\text { Remainder of } \\
\text { sample }\end{array}$ \\
\hline A. Did the firm apply for a loan? & Obs & $(\%)$ & Obs & $(\%)$ \\
Do not know & 16 & 2.83 & 93 & 4.36 \\
Yes & 193 & 34.1 & 477 & 22.3 \\
No & 357 & 63.0 & 1,564 & 73.2 \\
Total & 566 & & 2,134 & \\
\hline B. Main reason not to apply for a loan? & & & & \\
& Obs & $(\%)$ & Obs & $(\%)$ \\
Do not know & 2 & 0.56 & 19 & 1.21 \\
No need for a loan & 78 & 21.8 & 1,019 & 65.1 \\
Complicated application procedures & 44 & 12.3 & 168 & 10.7 \\
Interest rates are not favourable & 74 & 20.7 & 116 & 7.42 \\
Collateral requirements too high & 74 & 20.7 & 89 & 5.69 \\
Insufficient loan size and maturity & 44 & 12.3 & 82 & 5.24 \\
Did not think it would be approved & 30 & 8.40 & 52 & 3.32 \\
Other & 11 & 3.08 & 19 & 1.21 \\
Total & 357 & & 1,564 & \\
\hline
\end{tabular}

Notes: Question B (Main reason not to apply for a loan?) is only relevant for firms that replied 'No' to Question A (Did the firm apply for a loan?). A small proportion of firms did not report any of these answers and chose to declare 'Do not know'. Firms are divided in two samples: the sample of firms that state their main obstacle is access to finance and the sample of firms for which the main obstacle is other than access to finance. 
Table 3. Summary statistics table

\begin{tabular}{lrrrrr}
\hline Variable & Obs & Mean & Std. Dev. & Min. & Max. \\
\hline & & & & & \\
$\quad$ Investment and access to credit & & & & & \\
& 2,588 & 0.31 & 0.46 & 0 & 1 \\
Access to credit dummy: 1 if firm has a loan & 536 & 20,850 & 83,190 & 0.001 & $1,000,000$ \\
Loans: amount of loans (RMB 1,000) & 2,678 & 0.51 & 0.50 & 0 & 1 \\
Investment decision dummy: 1 if firm invests in 2011 & 1,131 & 6,221 & 51,876 & $7,035,569$ & $1,500,000$ \\
Investment: amount of investment in 2011 (RMB1,000) & 195 & 543,098 & $2,201,329$ & 1,560 & $20,000,000$ \\
Investment financed by the financial sector (RMB 1,000) & & & & & \\
$\quad$ Joint determinants of investment and credit & 2,699 & 248.0 & $1,127.3$ & 5 & 30,100 \\
Employment: full-time (permanent \& temp.) employees & 2,699 & 0.22 & 0.42 & 0 & 1 \\
SME1 dummy: 20 or less full-time employees & 2,699 & 0.37 & 0.48 & 0 & 1 \\
SME2 dummy: between 20 \& 100 full-time employee & 2,698 & 10.87 & 24.63 & 0 & 100 \\
Exports: as \% of sales (direct and indirect exports) & 2,692 & 3.81 & 16.91 & 0 & 100 \\
Foreign: \% of foreign ownership & 2,692 & 3.04 & 15.45 & 0 & 95 \\
State: \% of government or state ownership & 2,698 & 0.24 & 0.43 & 0 & 1 \\
Exporter dummy: 1 if exports > 50\% & 2,692 & 0.06 & 0.24 & 0 & 1 \\
Foreigner dummy: 1 if foreign ownership > 50\% & 2,692 & 0.04 & 0.20 & 0 & 1 \\
State dummy:1 if government or state ownership > 50\% & 2,640 & 16.34 & 7.52 & 1 & 55 \\
Manager experience (in years) & 2,700 & 0.39 & 0.49 & 0 & 1 \\
Female owner (dummy): 1 if there is a female owner & 2,696 & 0.89 & 0.31 & 0 & 1 \\
Female manager (dummy): 1 if the manager is female & 2,627 & 12.72 & 7.91 & 0 & 125 \\
Age (in years) & 2,408 & 8.89 & 11.20 & -15.45 & 53.86 \\
Growth: growth of sales & 2,660 & 877.9 & $6,136.3$ & -100.0 & 247,834 \\
Profit: margin of sales over cost & & & & & 1 \\
BIZ dummy: 1 if the firm belongs to a business group & 2,700 & 0.13 & 0.34 & 0 & 1 \\
Listed dummy: 1 if the firm is a listed company & 2,700 & 0.02 & 0.14 & 0 & 0 \\
Land dummy 1 if the firm owns > 50\% of the land & 2,624 & 0.51 & 0.50 & 0 & 1 \\
\hline
\end{tabular}

Source: All variables are from the 2012 World Bank Enterprise Survey for China. Monetary values are in renminbi. 
Table 4. Credit in SME firms

\begin{tabular}{|c|c|c|c|c|c|c|c|}
\hline & (1) & (2) & (3) & (4) & (5) & (6) & (7) \\
\hline Employment (log) & $\begin{array}{l}0.878^{* * *} \\
(0.115)\end{array}$ & $\begin{array}{l}0.735^{* * *} \\
(0.196)\end{array}$ & $\begin{array}{l}0.649^{* * * *} \\
(0.167)\end{array}$ & $\begin{array}{l}0.651 * * * \\
(0.167)\end{array}$ & $\begin{array}{l}0.643 * * * \\
(0.167)\end{array}$ & $\begin{array}{l}0.609 * * * \\
(0.170)\end{array}$ & $\begin{array}{l}0.538^{* * *} \\
(0.184)\end{array}$ \\
\hline Empl (log) squared & $\begin{array}{l}-0.058^{* * *} \\
(0.012)\end{array}$ & $\begin{array}{l}-0.045^{* * *} \\
(0.017)\end{array}$ & $\begin{array}{l}-0.040^{* * *} \\
(0.015)\end{array}$ & $\begin{array}{l}-0.040^{* * *} \\
(0.015)\end{array}$ & $\begin{array}{l}-0.039 * * \\
(0.015)\end{array}$ & $\begin{array}{l}-0.037 * * \\
(0.016)\end{array}$ & $\begin{array}{l}-0.030^{*} \\
(0.017)\end{array}$ \\
\hline SME1 dummy & & $\begin{array}{l}-0.165 \\
(0.222)\end{array}$ & $\begin{array}{l}-0.271^{*} \\
(0.146)\end{array}$ & $\begin{array}{l}-0.274^{*} \\
(0.146)\end{array}$ & $\begin{array}{l}-0.271^{*} \\
(0.146)\end{array}$ & $\begin{array}{l}-0.287^{*} \\
(0.150)\end{array}$ & $\begin{array}{l}-0.471 * * * \\
(0.165)\end{array}$ \\
\hline SME2 dummy & & $\begin{array}{l}0.061 \\
(0.106)\end{array}$ & & & & & \\
\hline Exports & $\begin{array}{l}0.003 * * \\
(0.001)\end{array}$ & $\begin{array}{l}0.003 * * \\
(0.001)\end{array}$ & $\begin{array}{l}-0.004 * * \\
(0.002)\end{array}$ & $\begin{array}{l}-0.004 * * \\
(0.002)\end{array}$ & $\begin{array}{l}-0.004 * * \\
(0.002)\end{array}$ & $\begin{array}{l}-0.004 * * \\
(0.002)\end{array}$ & $\begin{array}{l}-0.003 \\
(0.002)\end{array}$ \\
\hline Foreign ownership & $\begin{array}{l}0.000 \\
(0.002)\end{array}$ & $\begin{array}{l}0.000 \\
(0.002)\end{array}$ & $\begin{array}{l}0.001 \\
(0.004)\end{array}$ & & & & \\
\hline State ownership & $\begin{array}{l}-0.005^{* *} \\
(0.002)\end{array}$ & $\begin{array}{l}-0.006^{* * *} \\
(0.002)\end{array}$ & $\begin{array}{l}-0.005 \\
(0.006)\end{array}$ & $\begin{array}{l}-0.005 * * \\
(0.002)\end{array}$ & $\begin{array}{l}-0.005^{* *} \\
(0.002)\end{array}$ & $\begin{array}{l}-0.005^{* *} \\
(0.002)\end{array}$ & $\begin{array}{l}-0.005^{* *} \\
(0.002)\end{array}$ \\
\hline Exporter dummy & & & $\begin{array}{l}0.565^{* * *} \\
(0.117)\end{array}$ & $\begin{array}{l}0.564 * * * \\
(0.116)\end{array}$ & $\begin{array}{l}0.554 * * * \\
(0.117)\end{array}$ & $\begin{array}{l}0.570^{* * *} \\
(0.119)\end{array}$ & $\begin{array}{l}0.581 * * * \\
(0.126)\end{array}$ \\
\hline Foreign dummy & & & $\begin{array}{l}-0.051 \\
(0.254)\end{array}$ & & & & \\
\hline State dummy & & & $\begin{array}{l}-0.013 \\
(0.433)\end{array}$ & & & & \\
\hline Manager experience & $\begin{array}{l}0.008^{*} \\
(0.004)\end{array}$ & $\begin{array}{l}0.008 * \\
(0.004)\end{array}$ & $\begin{array}{l}0.007^{*} \\
(0.004)\end{array}$ & $\begin{array}{l}0.007 * \\
(0.004)\end{array}$ & $\begin{array}{l}0.007 \\
(0.005)\end{array}$ & $\begin{array}{l}0.007 * \\
(0.004)\end{array}$ & $\begin{array}{l}0.010^{* *} \\
(0.005)\end{array}$ \\
\hline BIZ group dummy & $\begin{array}{l}0.021 \\
(0.097)\end{array}$ & $\begin{array}{l}0.020 \\
(0.097)\end{array}$ & $\begin{array}{l}0.016 \\
(0.098)\end{array}$ & $\begin{array}{l}0.017 \\
(0.097)\end{array}$ & & & \\
\hline Listed dummy & $\begin{array}{l}0.176 \\
(0.210)\end{array}$ & $\begin{array}{l}0.149 \\
(0.210)\end{array}$ & $\begin{array}{l}0.102 \\
(0.212)\end{array}$ & $\begin{array}{l}0.102 \\
(0.212)\end{array}$ & & & \\
\hline Female owner & & & & $\begin{array}{l}0.066 \\
(0.074)\end{array}$ & & & \\
\hline Female manager & & & & $\begin{array}{l}-0.044 \\
(0.104)\end{array}$ & & & \\
\hline Age & & & & & $\begin{array}{l}0.000 \\
(0.004)\end{array}$ & & \\
\hline Land dummy & & & & & & $\begin{array}{l}0.141^{* *} \\
(0.070)\end{array}$ & $\begin{array}{l}0.123 \\
(0.077)\end{array}$ \\
\hline Growth (sales) & & & & & & & $\begin{array}{l}0.009 * * * \\
(0.003)\end{array}$ \\
\hline Profit & & & & & & & $\begin{array}{l}0.000 * * \\
(0.000)\end{array}$ \\
\hline Constant & $\begin{array}{l}-4.036^{* * *} \\
(0.371) \\
\end{array}$ & $\begin{array}{l}-3.691 * * * \\
(0.638)\end{array}$ & $\begin{array}{l}-3.424 * * * \\
(0.500)\end{array}$ & $\begin{array}{l}-3.430 * * * \\
(0.529)\end{array}$ & $\begin{array}{l}-3.395^{* * *} \\
(0.501) \\
\end{array}$ & $\begin{array}{l}-3.367 * * * \\
(0.505) \\
\end{array}$ & $\begin{array}{l}-3.533 * * * \\
(0.562) \\
\end{array}$ \\
\hline Observations & 2,529 & 2,529 & 2,529 & 2,528 & 2,464 & 2,463 & 2,197 \\
\hline Log-likelihood & -1157 & -1155 & -1143 & -1143 & -1130 & -1108 & -952.5 \\
\hline Credit $=$ Yes & 786 & 786 & 786 & 785 & 784 & 765 & 678 \\
\hline
\end{tabular}

Notes: Robust standard errors in parentheses, ${ }^{* * *} \mathrm{p}<0.01,{ }^{* *} \mathrm{p}<0.05,{ }^{*} \mathrm{p}<0.1$. All regressions include city and industry fixed effects. 
Table 5. Investment

\begin{tabular}{|c|c|c|c|c|c|c|}
\hline & $(8)$ & (9) & $(10)$ & (11) & (12) & (13) \\
\hline Credit & $\begin{array}{l}0.482 * * * \\
(0.069)\end{array}$ & $\begin{array}{l}0.483 * * * \\
(0.069)\end{array}$ & $\begin{array}{l}0.462 * * * \\
(0.070)\end{array}$ & $\begin{array}{l}0.473 * * * \\
(0.070)\end{array}$ & $\begin{array}{l}0.467 * * * \\
(0.070)\end{array}$ & $\begin{array}{l}0.433 * * * \\
(0.076)\end{array}$ \\
\hline Employment (log) & $\begin{array}{l}0.544 * * * \\
(0.103)\end{array}$ & $\begin{array}{l}0.415^{* *} \\
(0.171)\end{array}$ & $\begin{array}{l}0.538^{* * *} \\
(0.104)\end{array}$ & $\begin{array}{l}0.528^{* * * *} \\
(0.103)\end{array}$ & $\begin{array}{l}0.531 * * * \\
(0.105)\end{array}$ & $\begin{array}{l}0.516^{* * * *} \\
(0.113)\end{array}$ \\
\hline Empl. (log) squared & $\begin{array}{l}-0.033 * * * \\
(0.011)\end{array}$ & $\begin{array}{l}-0.025^{*} \\
(0.015)\end{array}$ & $\begin{array}{l}-0.033 * * * \\
(0.011)\end{array}$ & $\begin{array}{l}-0.032 * * * \\
(0.011)\end{array}$ & $\begin{array}{l}-0.032 * * * \\
(0.011)\end{array}$ & $\begin{array}{l}-0.033 * * * \\
(0.012)\end{array}$ \\
\hline SME1 dummy & & $\begin{array}{l}-0.219 \\
(0.194)\end{array}$ & & & & \\
\hline SME2 dummy & & $\begin{array}{l}-0.135 \\
(0.098)\end{array}$ & & & & \\
\hline Exports & $\begin{array}{l}0.002 * \\
(0.001)\end{array}$ & $\begin{array}{l}0.002 * \\
(0.001)\end{array}$ & $\begin{array}{l}-0.002 \\
(0.002)\end{array}$ & & & \\
\hline Foreign ownership & $\begin{array}{l}0.001 \\
(0.002)\end{array}$ & $\begin{array}{l}0.001 \\
(0.002)\end{array}$ & $\begin{array}{l}0.002 \\
(0.004)\end{array}$ & & & \\
\hline State ownership & $\begin{array}{l}-0.014 * * * \\
(0.002)\end{array}$ & $\begin{array}{l}-0.014 * * * \\
(0.002)\end{array}$ & $\begin{array}{l}-0.024 * * * \\
(0.006)\end{array}$ & $\begin{array}{l}-0.014 * * * \\
(0.002)\end{array}$ & $\begin{array}{l}-0.014 * * * \\
(0.002)\end{array}$ & $\begin{array}{l}-0.014 * * * \\
(0.002)\end{array}$ \\
\hline Exporter dummy & & & $\begin{array}{l}0.369^{* * *} \\
(0.117)\end{array}$ & $\begin{array}{l}0.261 * * * \\
(0.072)\end{array}$ & $\begin{array}{l}0.270 * * * \\
(0.074)\end{array}$ & $\begin{array}{l}0.250^{* * * *} \\
(0.078)\end{array}$ \\
\hline Foreigner dummy & & & $\begin{array}{l}-0.059 \\
(0.244)\end{array}$ & & & \\
\hline State dummy & & & $\begin{array}{l}0.763 * \\
(0.432)\end{array}$ & & & \\
\hline Manager experience & $\begin{array}{l}0.009^{* *} \\
(0.004)\end{array}$ & $\begin{array}{l}0.009^{* *} \\
(0.004)\end{array}$ & $\begin{array}{l}0.009^{* *} \\
(0.004)\end{array}$ & $\begin{array}{l}0.009 * * \\
(0.004)\end{array}$ & $\begin{array}{l}0.012 * * * \\
(0.004)\end{array}$ & $\begin{array}{l}0.010^{* *} \\
(0.004)\end{array}$ \\
\hline Female owner & & & & $\begin{array}{l}-0.232 * * * \\
(0.066)\end{array}$ & $\begin{array}{l}-0.237 * * * \\
(0.066)\end{array}$ & $\begin{array}{l}-0.247 * * * \\
(0.069)\end{array}$ \\
\hline Female manager & & & & $\begin{array}{l}0.026 \\
(0.098)\end{array}$ & & \\
\hline Age & & & & & $\begin{array}{l}-0.007^{*} \\
(0.004)\end{array}$ & \\
\hline Growth (sales) & & & & & & $\begin{array}{l}0.014 * * * \\
(0.003)\end{array}$ \\
\hline Profit & & & & & & $\begin{array}{l}-0.000 \\
(0.000)\end{array}$ \\
\hline Constant & $\begin{array}{l}-2.602 * * * \\
(0.311)\end{array}$ & $\begin{array}{l}-2.107 * * * \\
(0.548)\end{array}$ & $\begin{array}{l}-2.597 * * * \\
(0.312)\end{array}$ & $\begin{array}{l}-2.298 * * * \\
(0.366)\end{array}$ & $\begin{array}{l}-2.230 * * * \\
(0.333)\end{array}$ & $\begin{array}{l}-2.461 * * * \\
(0.364)\end{array}$ \\
\hline Observations & 2509 & 2509 & 2509 & 2508 & 2448 & 2230 \\
\hline Log-likelihood & -1434 & -1433 & -1427 & -1423 & -1382 & -1251 \\
\hline Invest $=$ Yes & 1300 & 1300 & 1300 & 1300 & 1276 & 1154 \\
\hline Credit $=$ Yes & 782 & 782 & 782 & 781 & 780 & 691 \\
\hline $\begin{array}{l}\text { Endogeneity test } \\
\text { (p-value) }\end{array}$ & $\begin{array}{c}0.347 \\
(0.556)\end{array}$ & $\begin{array}{c}0.306 \\
(0.580)\end{array}$ & $\begin{array}{c}0.285 \\
(0.593)\end{array}$ & $\begin{array}{c}0.288 \\
(0.592)\end{array}$ & $\begin{array}{c}0.551 \\
(0.458)\end{array}$ & $\begin{array}{c}0.137 \\
(0.711)\end{array}$ \\
\hline
\end{tabular}

Notes: Robust standard errors in parentheses, ${ }^{* * *} \mathrm{p}<0.01,{ }^{* *} \mathrm{p}<0.05,{ }^{*} \mathrm{p}<0.1$. All regressions include city and industry fixed effects. The endogeneity test of access to credit makes use of SME1, the land ownership dummy and profitability as instrumental variables, except regressions (9), where SME1 is not an instrument, and (13), where profitability is not considered as an instrument. 
Table 6. Loans and investment

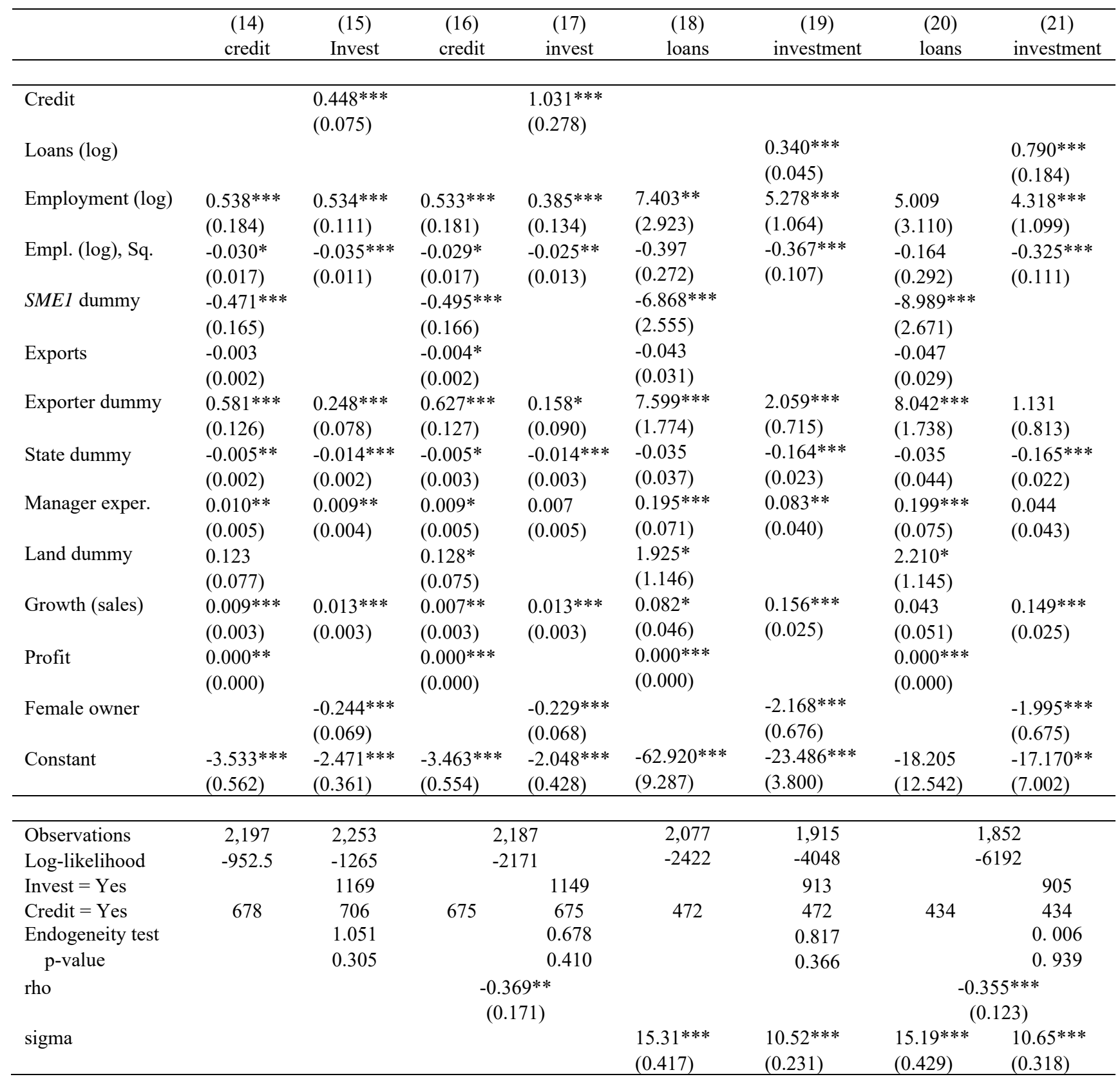

Notes: Robust standard errors in parentheses, ${ }^{* * *} \mathrm{p}<0.01,{ }^{* *} \mathrm{p}<0.05,{ }^{*} \mathrm{p}<0.1$. All regressions include city and industry fixed effects. At the bottom of the table, two additional estimates are included (and their standard errors in parentheses): the contemporary correlation coefficient between the error term of the two equations (rho) and the standard deviation of the error terms (sigma). 
Figure 1. Access to credit and firm size of exporters and non-exporters
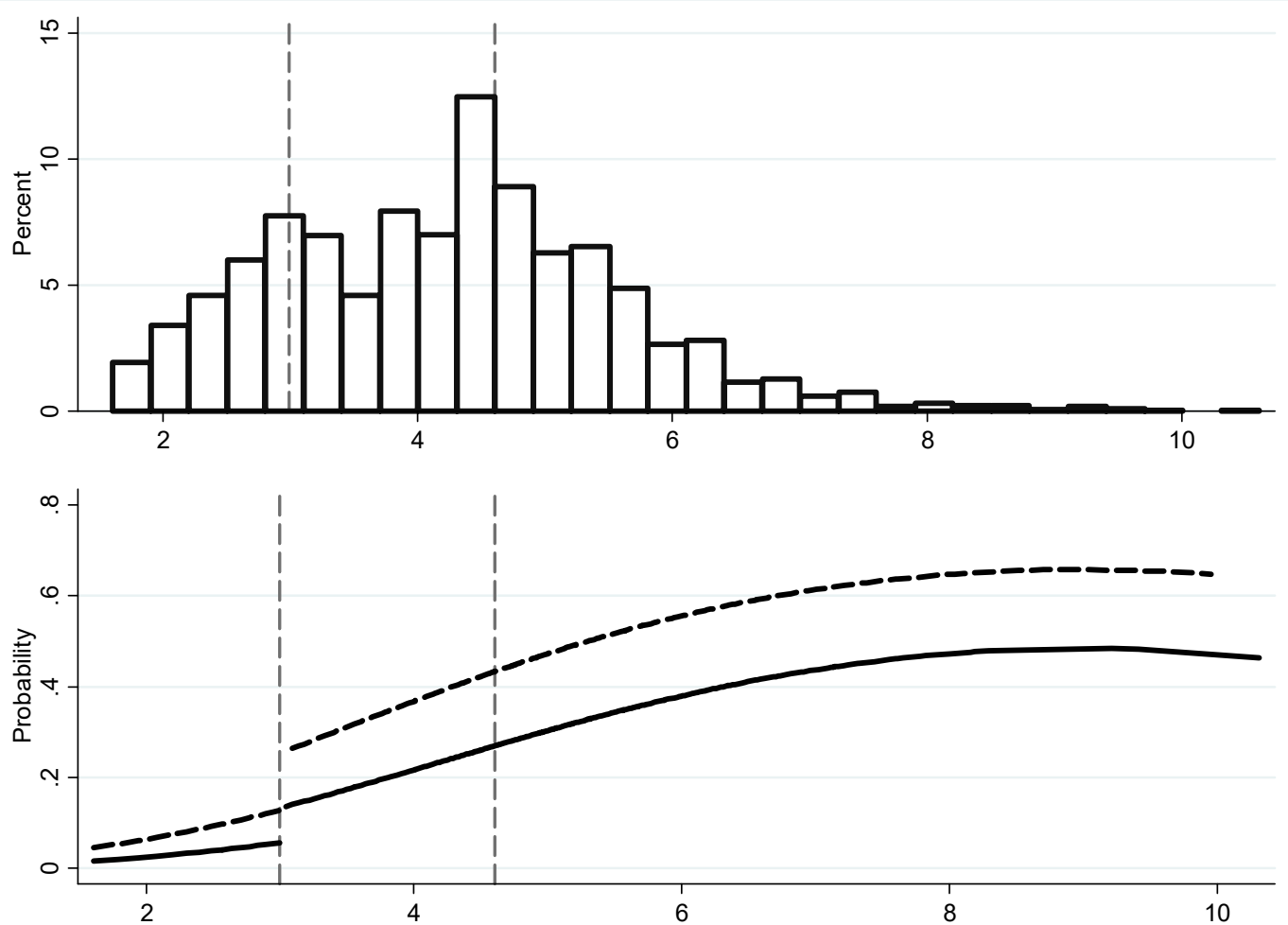

Notes: The histogram of firm size (employees, in logs) is at the top where the two vertical dashed lines divide small $(<3)$ and large (>4.6) firms. The effect of firm size on the probability of access to credit based on regression (7) is observed at the bottom. The dashed and solid black lines correspond to firms that export and firms that exclusively serve the domestic market, respectively. The turning point is at 8.99 of the log of employment (i.e. 8,000 employees), with less than $0.3 \%$ of observations to the right. All variables other than employment are fixed at their sample mean. 
Figure 2: Investment, firm size and access to credit
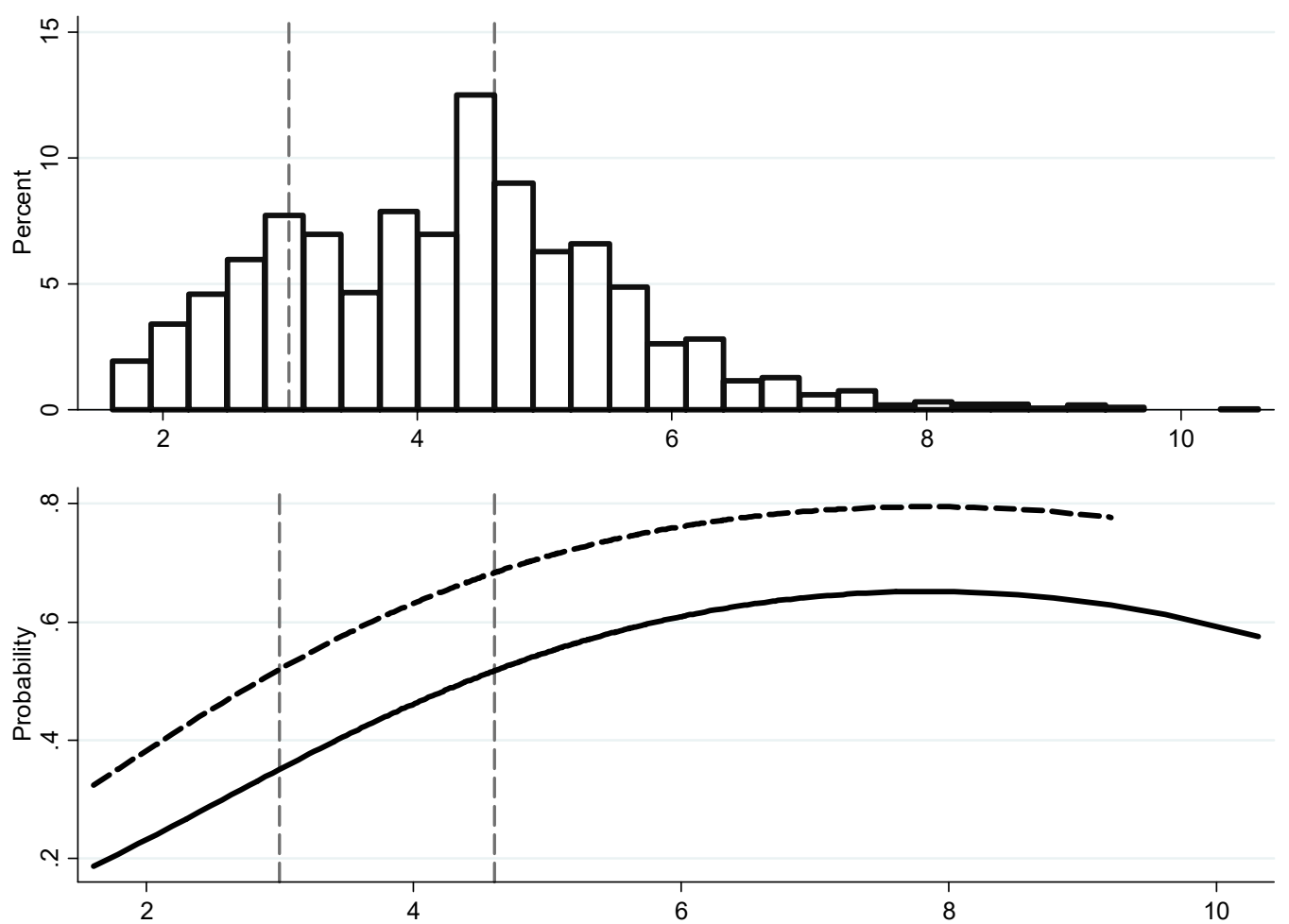

Notes: The top is the histogram of firm size (in logs) while the dotted vertical lines distinguish small $(<3)$ and large $(>4.6)$ firms. The bottom graph shows the effect of firm size and access to credit on the probability of investing, based on regression (13). The dashed and solid black lines correspond to firms with and without access to credit, respectively. The turning point is at 7.82 of the log of employment (i.e. 2,500 employees), with $1.2 \%$ of observations to the right. All variables other than employment and access to credit are fixed at their sample mean. 